Radoslav Z. Rajković

Research Assistant

University of Belgrade

Faculty of Mechanical Engineering Innovation Center

Serbia

Nenad Đ. Zrnić

Full Professor

University of Belgrade

Faculty of Mechanical Engineering

Serbia

Snežana D. Kirin

Assistant Professor

University of Belgrade

Faculty of Mechanical Engineering Innovation Cente

Branislav M. Dragović

Full Professor

University of Montenegro

Maritime faculty

Montenegro

\section{A Review of Multi-Objective Optimization of Container Flow Using Sea and Land Legs Together}

Intermodal freight transportation refers to a multi-modal chain of container-transportation services which usually links the initial shipper to the final consignee of the container (door-to-door service) and takes place over long distances. Container transportation is a major component of intermodal transportation and international commerce. Container flow should be optimal to ensure proper resource utilization and profitability to players. Various multi-objective evolutionary algorithms have been developed to efficiently solve optimization problems in container flows. This paper presents a short review of optimization problems in intermodal transport using sea and land legs together regarding three mostly observed objectives (transport cost, transit time and $\mathrm{CO}_{2}$ emissions).

Keywords: intermodal transport, container flows, multi-objective optimization.

\section{INTRODUCTION}

Contrary to conventional transportation systems intermodal freight transport involves the transportation of freight in an intermodal container or vehicle, using multiple modes of transportation (rail, ship, and truck), without any handling of the freight itself when changing modes. The method reduces cargo handling, and so improves security, reduces damage and loss, and allows freight to be transported faster. It can be said that in today's world, intermodal transportation forms the backbone of the world trade. The fundamental idea of intermodal transportation is to consolidate loads for efficient long-haul transportation (by rail or large ocean vessels), while taking advantage of the efficiency of local pick-up and delivery operations by truck. This explains the importance of container-based transportation, [1].

For many decades, containerized trade has been the fastest-growing market segment accounting for over 16 per cent of global seaborne trade by volume in 2012 and more than half by value in 2007 . With containerization being closely associated with globalization and fragmentation of global production, a recent study considering 157 countries over the 1962-1990 period provided empirical evidence that containerization is the driver of the twentieth century economic globalization. For a long time, containerized trade flows could be predicted by looking at the performance of world GDP with the multiplier effect of the container volume growth ranging between three to four times the GDP growth. Containerized trade volumes expanded in 2012 to reach 155 million TEUs. Containerized trade, which accounted for 65 per cent of "other dry cargo" in 2012 (that is, nearly two thirds of the 2.28 billion tons of dry

Received: December 2014, Accepted: December 2015

Correspondence to: M.Sc Radoslav Rajković

Faculty of Mechanical Engineering,

Kraljice Marije 16, 11120 Belgrade 35, Serbia

E-mail: rrajkovic@mas.bg.ac.rs

doi:10.5937/fmet1602204R

(C) Faculty of Mechanical Engineering, Belgrade. All rights reserved cargo that remain after removing dry-bulk commodities), increased by 3.2 per cent in 2012 , down from 13.1 per cent in 2010 and 7.1 per cent in 2011, [2].

Global container trade between 1996 and 2013 is presented in Figure 1, [2].

The usage of containers shows the complementarity between freight transportation modes by offering a higher fluidity to movements and a standardization of loads. The container has substantially contributed to the adoption and diffusion of intermodal transportation which has led to profound mutations in the transport sector. Through reduction of handling time, labor costs, and packing costs, container transportation allows considerable improvement in the efficiency of transportation. Thus, the relevance of containers is not what they are - simple boxes - but what they enable; intermodalism. Globalization could not have taken its current form without containerization. Intermodalism originated in maritime transportation, with the development of the container in the late 1960's and has since spread to integrate other modes. It is not surprising that the maritime sector should have been the first mode to pursue containerization. It was the mode most constrained by the time taken to load and unload the vessels. A conventional breakbulk cargo ship could spend as much time in a port as it did at sea. Containerization permits the mechanized handling of cargoes of diverse types and dimensions that are placed into boxes of standard sizes. In this way goods that might have taken days to be loaded or unloaded from a ship can now be handled in a matter of minutes, [3].

Containerization represents a revolution in the freight transport industry, facilitating both economies of scale and improvements in handling speed and throughput, with containerized traffic surging since the 1990s. This underlines the adoption of the container as a privileged mean to ship products on international and national markets, particularly for non bulk commodities where the container accounts for about $90 \%$ of all movements. Containerization leans on growth factors mainly related 


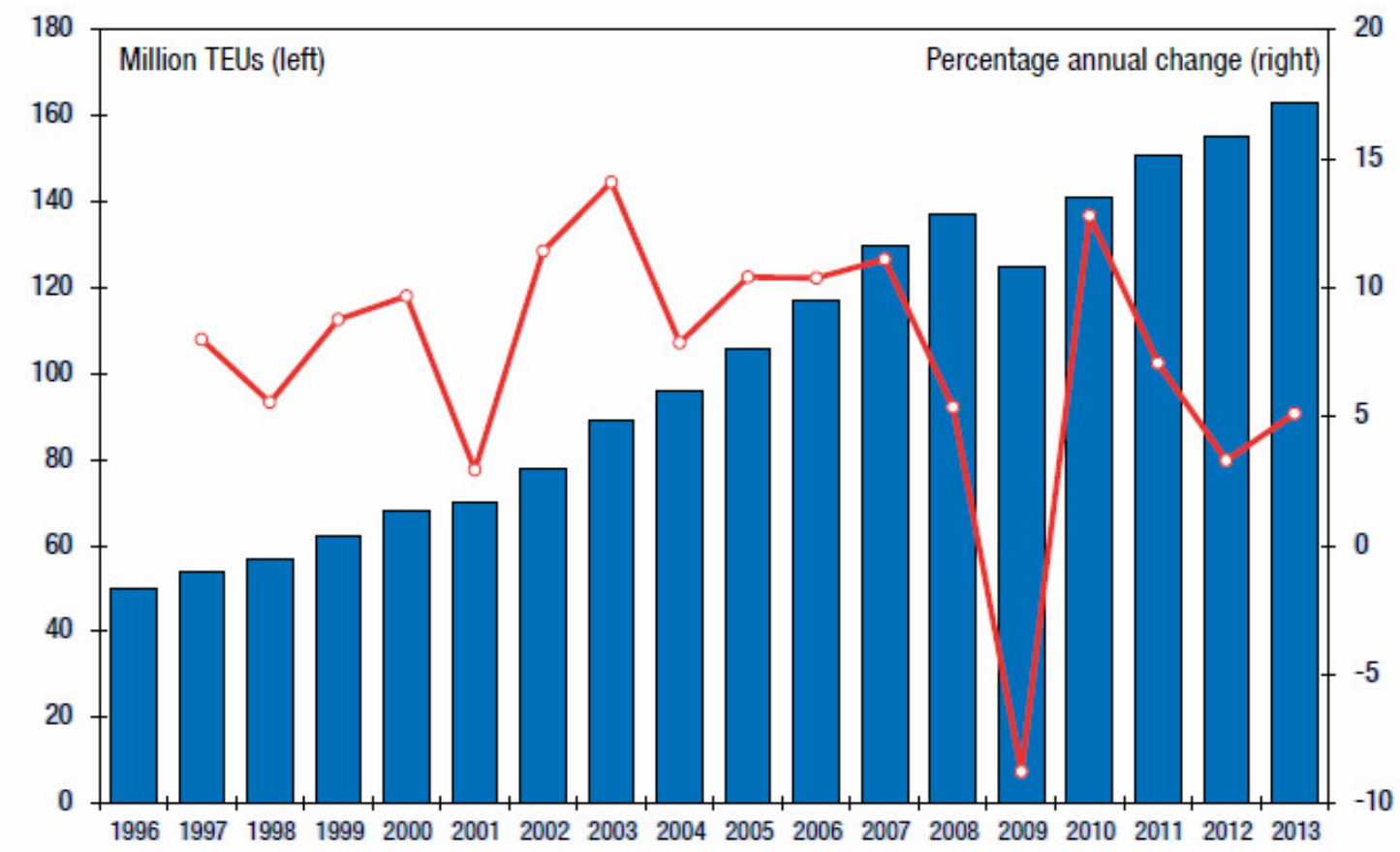

Source: Based on Drewry Shipping Consultants, Container Market Review and Forecast 2008/2009, and Clarkson Research Services, Container Intelligence Monthly, various issues.

Figure 1. Global container trade, 1996-2013

transshipment hubs. Globalization and containerization are closely interrelated. According to United Nations Conference on Trade And Development (UNCTAD), between 1970 and 1990 trade facilitation measures accounted for $45 \%$ of the growth in global trade while membership to global trade organization such as General Agreement on Tariffs and Trade (GATT)/World Trade Organisation (WTO) accounted for another $285 \%$. The container accounted for an additional $790 \%$, exceeding all the other trade growth factors put together. The diffusion and adaptation of transport modes to containerization is an ongoing process which will eventually reach a level of saturation. Containers have thus become the most important component for rail and maritime intermodal transportation. The challenge remains about the choice of modes in an intermodal transport chain as well as minimizing the costs and delays related to moving containers between modes, [3].

One of the most frequent fields of the observations in the container transport is optimization of container flows. Various multi-objective evolutionary algorithms have been developed to efficiently solve these optimization problems.

The rest of this paper is organized as follows: Section 2 describes the field of container flows while different optimization models are explained in Section 3. Section 4 reports about future developments and finally, Section 5 is devoted to conclusions.

\section{CONTAINER FLOWS}

Container flows are quite representative of global trade imbalances (Figure 2, [2]), which have steadily been growing since the mid 1990-s and up to 2008. For instance, there are 2.1 times as much containers moving from Asia to the United States (12.7 million TEUs in
2011) than vice-versa (6.0 million TEU), meaning that the equivalent of 6.7 million TEUs had to be repositioned across the Pacific. By 2005, about $70 \%$ of the slots of containerships leaving the United States were empty with major container ports such as Los Angeles handling large amounts of empty containers. The Asia-Europe trade route is facing a similar imbalance. It is not uncommon to see whole containerships being chartered solely to reposition empty containers. Thus, production and trade imbalances in the global economy are clearly reflected in imbalances in the physical flows of containers and transport rates. Maritime shippers spend on average $\$ 100$ billion per year to operate their container assets. Of this, about $\$ 16$ billion is spent repositioning empties.

For Transpacific trade, it costs more per TEU for eastbound flows than for westbound flows, making freight planning a complex task for container shipping companies. For Asia-Europe flows, westbound rates are higher than eastbound rates. Thus, production and trade imbalances in the global economy result in imbalances in physical flows and transport rates. Even if eastbound trans-Pacific rates are lower than westbound trans-Pacific rates, in theory conferring an advantage to American exports, costs differences are so in favor of Asia (China) that the American economy does not take much advantage of this benefit. There is however evidence that the growth of imbalances has receded. The global recession that was felt in 2009 lessened American and European imports from Asia substantially, [2].

The surge in container trade is mainly attributed to the increasing penetration of Asian products in developed European and American markets. In fact, container trade flows to and from Asia present the highest growth among the three main East-West trade routes (AsiaEurope, Transpacific and Transatlantic) which make 47 


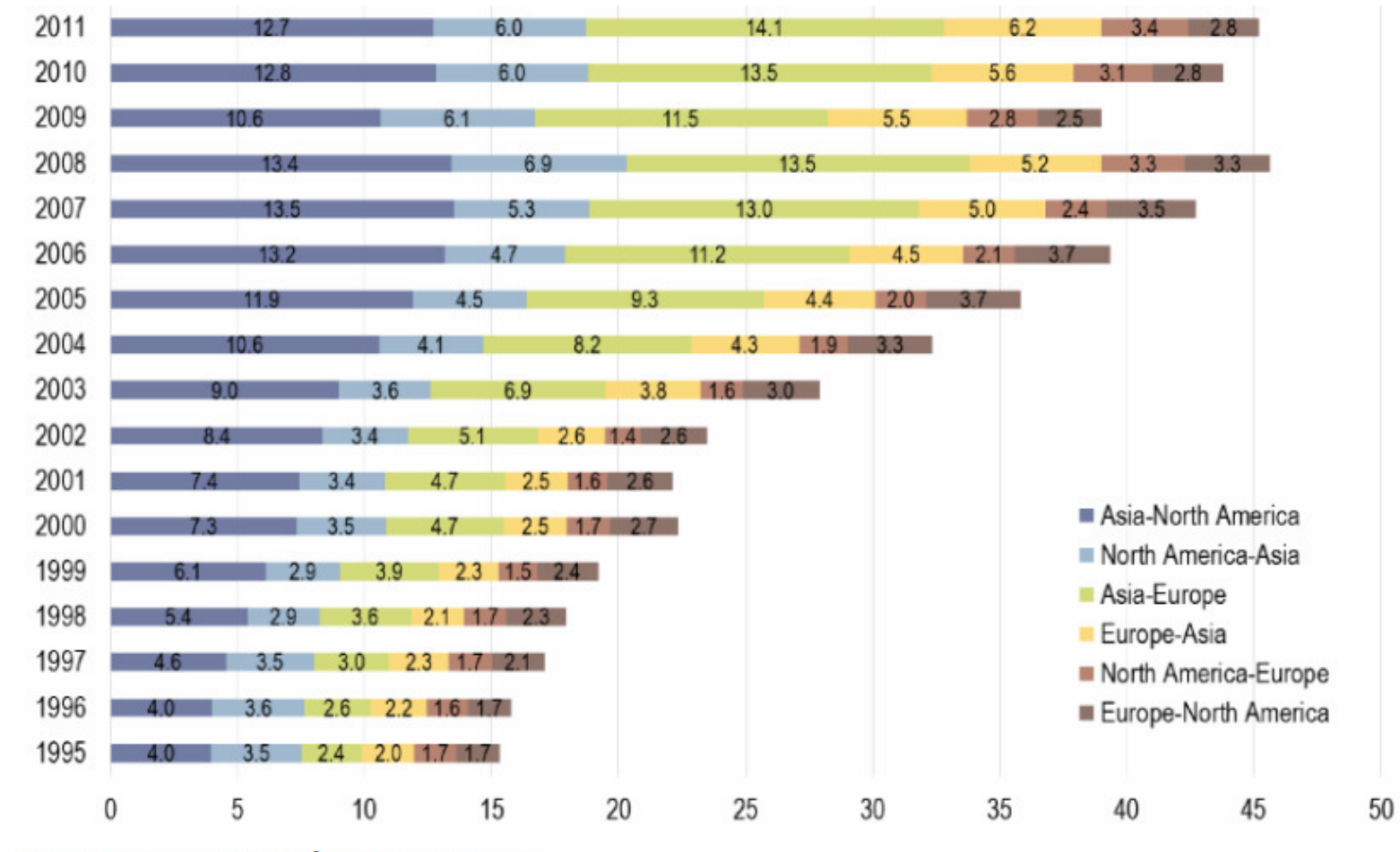

Source: UNCTAD, Review of Maritime Transport.

Figure 2. Containerized Cargo Flows along Major Trade Routes, 1995-2011 (in million TEUs)

per cent of world maritime container trade flows. Specifically, during the period 1995-2011, container trade has increased by almost 5 times between Asia and Europe reaching about 20 million TEUs. Between Far East and Mediterranean 4.37 million TEUs was shipped using 31 different liner shipping services in 2012, [2].

\section{OPTIMIZATION MODELS}

Generally, mathematical models designed to help us make "better" decisions. In mathematics, computer science, or management science, mathematical optimization (alternatively, optimization or mathematical programming) is the selection of a best element (with regard to some criteria) from some set of available alternatives. In the simplest case, an optimization problem consists of maximizing or minimizing a real function by systematically choosing input values from within an allowed set and computing the value of the function. The generalization of optimization theory and techniques to other formulations comprises a large area of applied mathematics. More generally, optimization includes finding "best available" values of some objective function given a defined domain (or a set of constraints), including a variety of different types of objective functions and different types of domains (Figure 3), [4].

For businesses to gain competitive advantage there is need to shorten delivery time by increasing flow of containers through supply chain nodes. Transport users require frequent, accurate and reliable implementation of transport. With the increase in the value of goods, increases the importance of speed transportation, as an important component of the supply chain. Container transport as programmed transport chain caused by the exact time harmonizing transport all participants in the chain. Deviations from schedules (sea, rail, road) leads to irregular deliveries - making delays and bottlenecks.
Considering the large and constant struggle in the market in terms of competitive pricing of products, a very important and indispensable role represents the container transport with a clear task to define the final price of the product, [5].

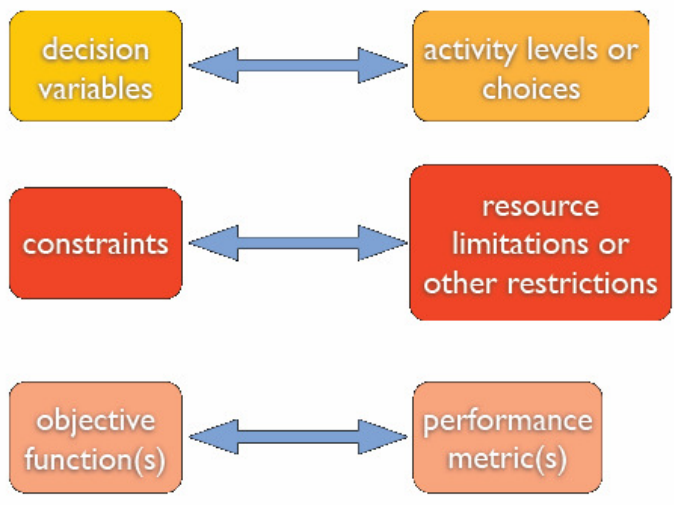

Figure 3. Nuts and bolts of optimization models

Some customers require lowest freight rates while others need faster delivery and making multi objective optimization is very seriouse task. It is recommended to managers who made a policy of the company, in order to improve their businesses following the constant changes in the market and making reliable comparisons, [6].

Cost and transit time are the two most common considerations in transport planning problems. Rising concerns about carbon dioxide $\left(\mathrm{CO}_{2}\right)$ emissions can therefore no longer be ignored when planning supply chains: on the one hand because companies have a moral obligation to operate in a sustainable fashion and on the other hand because customers are becoming more and more aware of the humongous affect that supply chain design has on $\mathrm{CO}_{2}$ emissions. Intermodal network development offers great potential to improve sustainability in supply chain and transportation because railway and inland barge transport incurs much lower 
carbon emissions than trucking which is now dominant in inland transport. This explains why green transport solutions suggest seaport linked with inland dry ports by railway especially double-stack train application, inland barge connections, and using shortest possible initial and final journeys by truck in intermodal container networks.

\section{a. Single objective optimization}

One of the most important tasks in the transportation of containers is the integration of container networks into a single network using different modes of transport. Studying literature data it was concluded that a small number of researchers investigated at the same time sea and land legs together [1], [7-10]. In most cases it is developed an optimization model which is based on the minimization for just one objective.

The main goal of Newman, A. M. and Yano, C. A. [11], was to minimize operating costs, including a fixed charge for each train, variable transportation and handling costs for each container and yard storage costs, while meeting on-time delivery requirements. They formulated the problem as an integer program and developed a novel decomposition procedure to find near-optimal solutions.

Francesetti D. C. [12], presented an analysis of the costs of shipping containers from four Chinese ports to representative central European destinations. It demonstrated that the sum of costs by sea and costs over land, using both truck and rail transport, clearly favours the Italian ports, above all those of Genoa and Trieste for a geographic range that does not include all the Northern countries of the European Union and Russia but does cover a considerable portion of the southernmost cities of these countries such as Milan, Munich, Vienna, Budapest, Bern, Lyon, and Kiev.

A multi-modal transportation problem considered by Kim et al. [9], was the problem of determining the transportation flow, i.e. volume of container cargoes, and the transportation mode in each trade route, for the objective of minimizing the sum of shipping and inland transportation costs. The problem takes into account two restrictions: maximum cargo volumes capacitated at each seaport and maximum number of vehicles available at each transportation mode. To solve optimally the problem, they employ a mixed integer programming, which is an operations research technique. A case study is performed on the container cargo data in Korea and they draw several implications to improve efficiency in the transportation of international trade cargoes in Korea.

Similar investigations next year were made by Infante et al. [8]. It focused on an intermodal freight transport service in which containers represent the moved loading units. In particular, it deals with the advantages of combining sea and road transportation sea for transferring large quantities over long distances, road for collecting and distributing over short or medium distances. With a view to minimizing the total cost of the service, they formulated a ship-truck intermodal transportation problem as a Travelling Purchaser Problem (TPP), in this way broadening the real-world applications field of the TPP.
Han et al. [13], considered the problem of determining transportation quantity and mode in transporting international cargoes between Myanmar and her trading countries, especially focusing on the countries in South East Asia to check the extent of using short sea shipping, and inland transportation. The objective of their paper is to minimize transportation costs by mode between cargo origin and destination, subject to the maximum cargo volumes being handled at each seaport. In order to optimize the short sea shipping and inland transportation in Myanmar, their paper suggests a linear programming model, which is an operations research technique.

Payman, J. and Robert, C. L., [10] introduced an analytical model for predicting the allocation to ports and transportation channels of containerized goods imported from Asia to the USA. The first model, termed the Long-Run Model, is a large mixed integer nonlinear programming model, and a set of heuristics to solve that. The objective is to minimize the total costs for transportation and handling, pipeline inventory, and safety-stock inventories. The Short-Run Model uses the Long-Run model as a component and integrates it with a set of analytical queuing models which estimate the import container flow times through port terminals, rail intermodal terminals and rail line-haul channels as a function of traffic volumes, infrastructure and staffing hours.

Other methods described in the literature by Le Clercq and Le Chriqui are based on the idea of finding a least time path. But instead of defining the path in terms of consecutive segments of individual lines, paths are defined as a sequence of transfer nodes. While in the Le Clercqs method all direct lines are considered to be attractive, regardless of their in-vehicle time, Chriqui solves the problem of selecting the optimal subset of direct lines analytically. Fernside and Draper, Last and Leak and Scheele have proposed a network of design models that aim to optimize the frequencies of the lines by stating a normative objective function, [14].

Given the huge number of maritime services characterized by different frequencies, travel times and capacity, identifying the best path between each origindestination pair is not a trivial issue, and not one that may be solved by hand. Moreover, the optimal flow assignment for global travel time minimization on the network does not necessarily correspond to finding the shortest path from each origin to each destination, a problem widely addressed in the literature [15-17]. Maritime services frequencies may play a crucial role in the best path identification. Port processing times, duty check times and inland travel times may be also as important and depend and the magnitude of traffic at each port.

While earlier approaches were essentially based on choice models, in the 1980s general equilibrium principles were applied to freight networks, explaining simultaneously the generation, distribution, mode split and assignment of freight flows [18, 19]. Those models were extended in Crainic et al. [20] by introducing commodity differentiation, probabilistic choice models and inventory considerations. Chang [21] proposed a nonlinear model for best route selection on an 
international intermodal network which is not explicitly solved while solutions reported are obtained with a heuristic method.

Heinz Spiess and Michael Florian [14] described a model for transit assignment with a fixed set of transit lines and developed a label-setting algorithm that solves the latter problem in polynominal time.

Bell et al., [22], developed a model in which containers are carried by shipping lines operating strings (or port rotations) with given service frequencies. An origin-destination matrix of full containers is assigned to these strings to minimize sailing time plus container dwell time at the origin port and any intermediate transhipment ports. A paper necessitated two significant model extensions. The first involves the repositioning of empty containers so that a net outflow of full containers from any port is balanced by a net inflow of empty containers, and vice versa. As with full containers, empty containers are repositioned to minimize the sum of sailing and dwell time, with a facility to discount the dwell time of empty containers in recognition of the absence of inventory. The second involves the inclusion of an upper limit to the maximum number of container moves per unit time at any port.

Maurizio et al. [23] extended the frequency based approach introduced by Bell et al. [22] to an intermodal network, adding services capacity constraints, loading/ unloading and duty check times, while empty containers repositioning is not treated. It deals with container assignment optimization on an intermodal network and proposed a linear programming model. Computational results showed the efficiency and the effectiveness of the approach proposed, even on large size instances.

Schneider, O. [24] still focused on one objective$\mathrm{CO}_{2}$ emissions of cargo flows from Bangkok to Frankfurt and vice versa, specific and measurable aspect of sustainability, which help professionals in their practical decision making.

\section{b. Bi-objective optimization}

Bi-objective optimization is more reasonable and realistic than single objective optimization. In real-life situations, decision makers often need to deal with conflicting objectives. By inclusion of more objectives into the model we obtain accurate information to the observed objects at the same time.

Mostert, M. and Limbourg, S., [25] focused on the intermodal transport network design considering the total carbon dioxide emissions. It proposed a biobjective location-transportation model which deals with the assignment of the flows on the intermodal network in order to minimize the total transportation cost and the carbon dioxide emissions.

Xue, Y. D. and Irohara, T., [26] presented a study which minimizes both the transportation costs and $\mathrm{CO}_{2}$ emissions during transportation. This model considered a transportation scheduling problem in which loads are transported from an overseas production base to three domestic demand centers.

Similar research in terms of testing the bi-objective optimization minimizing cost and transit time conducted Lam, J. S. L. and Gu, Y., [7] observing import and export container flow to and from inland China. The results and analysis offer managerial insights of the impact of trade-offs between cost and transit time, and the effect of different carbon footprint requirements on transport planning.

Kim et al. [27] examined the relationship between the freight transport costs and the carbon dioxide $\left(\mathrm{CO}_{2}\right)$ emissions in given intermodal and truckonly freight networks. When the trade-off, which is represented as the relationship, is changed, the freight mode share and route choice are also modified. The tool that was developed is applied to a simplified freight transport network connecting two large European ports: the Port of Rotterdam (the Netherlands) and the Port of Gdansk (Poland). The initial solution, based on the minimization of freight costs, shows that the mode share of freight is local and regional freight transportation situations, whereas the other solutions balanced with $\mathrm{CO}_{2}$ emissions show that the mode share is changed into an intermodal freight system, which is based on a hub-and-spoke network.

\section{c. Multi-objective optimization}

Multi-objective optimization (also known as multiobjective programming, vector optimization, multicriteria optimization, multi-attribute optimization or Pareto optimization) is an area of multiple criteria decision making, that is concerned with mathematical optimization problems involving more than one objective function to be optimized simultaneously. Multi-objective optimization has been applied in many fields of science, including engineering, economics and logistics where optimal decisions need to be taken in the presence of trade-offs between two or more conflicting objectives.

As there usually exist multiple Pareto optimal solutions for multi-objective optimization problems, which means to solve such a problem is not as straightforward as it is for a conventional singleobjective optimization problem. Therefore, different researchers have defined the term "solving a multiobjective optimization problem" in various ways. Many methods convert the original problem with multiple objectives into a single-objective optimization problem. This is called a scalarised problem. If scalarisation is done carefully, Pareto optimality of the solutions obtained can be guaranteed. Solving a multi-objective optimization problem is sometimes understood as approximating or computing all or a representative set of Pareto optimal solutions. When decision making is emphasized, the objective of solving a multi-objective optimization problem is referred to supporting a decision maker in finding the most preferred Pareto optimal solution according to his/her subjective preferences. The underlying assumption is that one solution to the problem must be identified to be implemented in practice. Here, a human decision maker (DM) plays an important role. The DM is expected to be an expert in the problem domain. The most preferred solution can be found using different philosophies. Multi-objective optimization methods can be divided into four classes. In so-called no preference methods, no DM is expected to be available, but a 
neutral compromise solution is identified without preference information. The other classes are so-called a priori, a posteriori and interactive methods and they all involve preference information from the DM in different ways. In a priori methods, preference information is first asked from the DM and then a solution best satisfying these preferences is found. In a posteriori methods, a representative set of Pareto optimal solutions is first found and then the DM must choose one of them. In interactive methods, the decision maker is allowed to iteratively search for the most preferred solution. In each iteration of the interactive method, the DM is shown Pareto optimal solution(s) and describes how the solution(s) could be improved. The information given by the decision maker is then taken into account while generating new Pareto optimal solution(s) for the DM to study in the next iteration. In this way, the DM learns about the feasibility of his/her wishes and can concentrate on solutions that are interesting to him/her. The DM may stop the search whenever he/she wants to, [28].

Novikova et al. [29] presented multi-objective optimization of container flow through Dostyk and Alashankou. The paper had aims to contribute to body of research in application of multi-objective evolutionary algorithms in the area of transport and logistics. It reviewed various optimization approaches applicable to railway border stations focusing on aspects like time-tabling, platforming, rolling stock circulation, train shunting, line planning and crew planning. Throughput and cost data for Dostyk and Alashankou were analyzed using IMEA using Matlab software.

Yang et al. [30] developed an intermodal network optimization model to examine the competitiveness of 36 alternative routings for freight moving from China to and beyond Indian Ocean. The proposed model, which is built upon the principles of goal programming, is able to handle multiple and conflicting objective functions such as minimizing transportation cost, transit time and transit time variability while ensuring flow continuity and transit nodes compatibility among the rail, road, ocean vessel, airplane and inland waterway transports.

Winebrake et al. [31] presented an energy and environmental network analysis model to explore tradeoffs associated with freight transport. The geospatial model uses an intermodal network built by the authors to connect various modes (rail, road, water) via intermodal terminals. Routes along the network are characterized not only by temporal and distance attributes, but also by cost, energy, and emissions attributes (including emissions of carbon dioxide, particulate matter, sulfur oxides, volatile organic compounds, and oxides of nitrogen).

Tsung-Sheng, C. [32] formulated the international intermodal routing as a multiobjective multi-modal multicommodity flow problem (MMMFP) with time windows and concave costs. The objectives of his paper were to develop a mathematical model encompassing all three essential characteristics, and to propose an algorithm that can effectively provide answers to the model.

Min, H. [33] developed a chance-constrained goal programming model to aid the distribution manager in choosing the most effective intermodal mix that not only minimizes cost and risk, but also satisfies various on-time service reqirements.

\section{FUTURE RESEARCH}

Findings of this research show that optimization using immunized multi-objective evolutionary algorithm is a viable approach that can help managers who made a policy of the company, to improve their businesses following the constant changes in the market and making reliable comparisons.

The contribution of this paper is to give us a survey of achievements in a field of container transport flows using sea and legs together regarding different objectives.

Scrupulous observation of multi-objective optimization and analysis of applied algorithms, led us to the conclusion that the development of appropriate mathematical models can be an accurate way to answer the problem making simultaneous and significant multicriteria decision.

Studying literature data in this field, we conclude that the authors conducted the investigation of the transport of containers by different set of criteria optimization.

Future research raise the question of producing a single model that simultaneously performs single, biand multi- objective optimization in container transport for each of the most frequently mentioned and observed optimization problem in container transport flows such as transit time, transportation cost and gas emissions.

The above mentioned model should clearly show that solutions for each of the following criteria optimization in global container logistics networks use different modes of transport.

\section{CONCLUSION}

Optimization deals with the study of those kinds of problems in which one has to optimize one or more objectives that are functions of some real or integer variables. In most cases it is developed an optimization model which is based on the minimization for just one objective.

We concluded that bi-objective optimization is more reasonable and realistic than single objective optimization. By inclusion of more objectives into the model we obtain accurate information on the observed objects at the same time.

Multi-objective optimization has been applied in many fields of science, including engineering, economics and logistics where optimal decisions need to be taken in the presence of trade-offs between two or more conflicting objectives. Various multi-objective evolutionary algorithms have been developed to efficiently solve optimization problems in container flows.

This paper presents a review of optimization problems in intermodal transport using sea and land legs together regarding three mostly observed objectives transport cost, transit time and $\mathrm{CO} 2$ emissions.

\section{ACKNOWLEDGMENT}

The study was carried out within the Project TP 36027, "Software development and national database 
for strategic management of the development of means of transport and infrastructure in road, rail, air and water transport by European transport network models" and TR - 35006, "Sustainability and improvement of mechanical systems in energetic, material handling and conveying by using forensic engineering, environmental and robust design, financed by the Ministry of Education Science and Technological Development, Republic of Serbia.

\section{REFERENCES}

[1] Teodor, G. C., Kap, H. K.: Chapter 8 Intermodal Transportation, in: C. Barnhart and G. Laporte (Eds.): Handbooks in Operations Research and Management Science, Vol. 14, pp. 467-537, 2007.

[2] Review of Maritime Transport: UNCTAD/RMT/ 2013, United National Publication Sales no. E.13.II.D.9, ISBN 978-92-1-112872-7, e-ISBN 978-92-1-054195-4, ISSN 0566-7682.

[3] Rodrigue, J. P., Slack, B.: Intermodal Transportation and Containerization, in: Rodrigue, J. P., Comtois, C., Slack, B. (Ed.): The Geography of Transport Systems, Published 2006 by Routledge 2 Park Square, Milton Park, Abingdon, Oxon OX14 4RN, pp. 416, 2013.

[4] Hillier, F., Lieberman, G.: Introduction to operations research, 8th edition, 2005.

[5] Rajkovic, R., Zrnic, N., Stakic, Dj., Mahnic, B.: The Costs of Container Transport Flow Between Far East and Serbia Using Different Liner Shipping Services, in: Proceeding of the 11th International Conference on Logistics and Sustainable Transport, 19-21.06.2014, Celje, Slovenia, print ISSN 18543332, online ISSN 2232-4968.

[6] Rajkovic, R., Zrnic, N., Stakic, Dj.: Application of Mathematical Model for Container Transport Flow of Goods: from Far East to Serbia, in: Proceeding of the International Conference on Industrial Logistics, 11-13.06.2014, Brac, Croatia, pp. 75-82.

[7] Lam, J. S. L., Gu, Y.: Port Hinterland Intermodal Container Flow Optimization with Green Concerns: A Literature Review and Research Agenda, International Journal of Shipping and Transport Logistics (IJSTL), Vol. 5, Issue 3, pp. 257-281, 2013.

[8] Infante, D., Paletta, D., Vocaturo, F.: A Ship-truck Intermodal Transport Problem, Maritime Economics \& Logistics, Vol. 11 (3), pp. 247-259, 2009.

[9] Kim, H. J., Chang, Y. T., Lee, P. T. W., Sin, S. H., Kim, M. J.: Optimizing the Transportation of International Container Cargoes in Korea, Maritime Policy \& Management, Vol 35 (1), pp. 103-122, 2008.

[10] Payman, J., Robert, C. L.: Long- and Short-Run supply-chain optimization models for the allocation and congestion management of containerized imports from Asia to the United States, Transportation Research Part E, Vol. 47, pp. 593608, 2011.

[11] Newman A. M. and Yano C. A.: Scheduling Direct and Indirect Trains and Containers in an Intermodal
Setting, Transportation Science, Vol. 34, No. 3, pp. 256-270, 2000.

[12] Francesetti, D. C.: Italian versus Northern Range port competitiveness: a transportation cost analysis in Chinese trade, European Transport \ Trasporti Europei, Vol. 30, pp. 37-53, 2005.

[13]Han, M. M., Guolong, L. and Bin, Y.: A Linear Programming Model For Short Sea Shipping And Multi-modal Inland Transportation In Myanmar, Report and Opinion, Vol. 3, Issue 1, pp. 37-43, 2011.

[14] Spiess, H. and Florian, M.: Optimal strategies: A new assignment model for transit networks, Transportation Research Part B: Methodological, Vol. 23, Issue 2, pp. 83-102, 1989.

[15] Deo, N. and Pang, C. J.: Shortest-path algorithms: Taxonomy and annotation, Networks, Vol. 14, Issue 2, pp. 275-323, 1984.

[16]Festa, P.: Shortest Path Algorithms, in: M.G.C. Resende \& P.M. Pardalos (Eds.): Handbook of Optimization in Telecommunications, pp. 185-210, 2006.

[17] Gallo, G. and Pallottino, S.: Shortest path methods: A unifying approach, Mathematical Programming Studies, Vol. 26, pp. 38-64, 1986.

[18] Harker, P. T and Friesz, T. L.: Prediction of intercity freight flows, i: Theory, Transportation Research Part B, Vol. 20, Issue 2, pp. 139-153, 1986.

[19] Harker, P. T. and Friesz, T. L.: Prediction of intercity freight flows, ii: Mathematical formulation, Transportation Research Part B, Vol. 20, Issue 2, pp. 155-174, 1986.

[20] Crainic, T. G., Florian, M., Guelat, J. and Spiess. H.: Strategic planning of freight transportation: Stan, an interactive-graphical system, Transportation Research Record, 1283, pp. 97-124, 1990.

[21] Chang, T. S.: Best routes selection in international intermodal networks, Computers \& Operations Research, Vol. 35, Issue 9, pp. 2811 - 2891, 2008.

[22] Bell, M. G. H., et al.: A frequency-based maritime container assignment model, Transportation Research Part B, Vol. 45, pp. 1152-1161, 2011.

[23] Maurizio, A., Simona, M. and Andrea, R.: Formulating a mathematical model for container assignment optimization on an intermodal network. Procedia - Social and Behavioral Sciences, Vol. 111, pp. 1063-1072, 2014.

[24] Schneider, O.: A Conceptual Model to Facilitate Sustainable, Multi-modal Transportation Networks Between Thailand and Europe, BAWiSo-IBW, pp. 1-45, 2011.

[25] Mostert, M. and Limbourg, S.: A bi-objective model for intermodal transport, in: Proceedings of the 5th International Conference on Information Systems, Logistics and Supply Chain CONNECTING WORLDS ILS, Breda, 2014.

[26] Xue, Y. D. and Irohara, T.: A time-space network based international transportation scheduling problem incorporating $\mathrm{CO}_{2}$ emission levels, Journal 
of Zhejiang University - Science A (Applied Physics \& Engineering), Vol. 11, Issue 12, pp. 927 932, 2010.

[27] Kim, N. S., Janic, M. and Bert, V. W.: Trade-Off Between Carbon Dioxide Emissions and Logistics Costs Based on Multi-objective Optimization, Transportation Research Record: Journal of the Transportation Research Board, No. 2139, pp. 107116, 2009.

[28] Miettinen, K. M.: Nonlinear Multiobjective Optimization, USA, 1999.

[29] Novikova, K. K. A, Jing, L. and Kennedy, R. O.: A Multi-objective Optimization of Sino-Kazakh Container Flow through Dostyk-Alashankou, International Journal of Business, Humanities and Technology, Vol. 3, No. 7, pp. 37-47, 2013.

[30] Yang, X., Low, J. M. W., Tang, L. C.: Analysis of Intermodal Freight from China to Indian Ocean: A Goal Programming Approach, Journal of Transport Geography, Vol. 19, Issue 4, pp. 515-527, 2011.

[31] Winebrake, J. J., Corbett, J. J., Falzarano, A., Hawker, J. S., Korfmacher, K., Ketha, S. and Zilora, S.: Assessing Energy, Environmental, and Economic Tradeoffs in Intermodal Freight Transportation, Journal of the Air \& Waste Management Association, Vol. 58, Issue 8, pp. 1004-1013, 2008.

[32] Tsung-Sheng, C.: Best routes selection in international intermodal networks, Computers \& Operations Research, Vol. 35, Issue 9, pp. 2877 2891, 2008.

[33] Min, H.: International Intermodal Choices Via Chance-Constrained Goal Programming, Transpor- tation Research Part A: Policy and Practice, Vol. 25A, Issue 6, 1991.

\section{ПРЕГЛЕД ВИШЕКРИТЕРИЈУМСКЕ ОПТИМИЗАЦИЈЕ У ТРАНСПОРТУ КОНТЕЈНЕРА КОРИШЋЕНЕМ КОМБИНОВАНИХ МОРСКИХ И КОПНЕНИХ ТРАНСПОРТНИХ ЛАНАЦА}

\section{Радослав 3. Рајковић, Ненад Ђ. Зрнић, Снежана Д. Кирин, Бранислав М. Драговић}

Интермодални транспорт је систем који подразумева превоз “од врата до врата" под одговорношћу једног превозника тј. оператора интермодалног транспорта, уз учешће најмање два вида транспорта (у превозу терета без промене товарно манипулативне јединице). Контејнерски транспорт је главна компонента интермодалног транспорта и међународне трговине. Контејнерски транспортни ток би требало да буде оптималан како би се осигурало правилно коришћење ресурса и како би се омогућила профитабилност корисника. Разни вишекритеријумски еволуциони алгоритми су развијени да ефикасно реше проблеме оптимизације у контејнерерском транспорту. Овај рад представља кратак преглед проблема оптимизације у интермодалном транспорту посматрајући један транспортни ланац у коме се транспорт контејнера обавља морем и копном узимајући у обзир три најчешће разматрана оптимизациона критеријума (транспортни трошкови, транзитно време и емисија угљен-диоксида). 